\title{
A Radical Case for Open Borders
}

\author{
Bryan Caplan \\ Department of Economics, \\ Center for Study of Public Choice, \\ and Mercatus Center \\ George Mason University \\ Fairfax, VA 22030 \\ bcaplan@gmu.edu \\ 703-993-2324 \\ Vipul Naik
}

Ph.D. Mathematics, University of Chicago

Contract researcher, Machine Intelligence Research Institute vipulnaik1@gmail.com

773-470-5711

May, 2014

We thank Zachary Gochenour and Nathaniel Bechhofer for excellent research assistance, Alex Nowrasteh, Carl Shulman, Hansjoerg Walther, and seminar participants at Texas Tech for helpful suggestions, and the Public Choice Center, Mercatus Center, and Free Market Institute for financial support. 


\section{Introduction}

Suppose you get laid off in Oklahoma. Local opportunities are sparse, so you find a job in California, rent a new place, and go. Voila, your move is done. You need not get permission from a government official or convince anybody that your presence is a net positive for California. ${ }^{1}$ That's because the member states of the United States have open borders.

This chapter argues in favor of global open borders. In an open borders world, you don't need permission to move from Lahore to London or Montreal to Mumbai any more than you need permission to move from Oklahoma to California. The case for open borders is universal: it applies to the United States, Australia, Japan, India, China, Germany, and all other countries. For the most part, though, we focus on the modern United States, with occasional discussion of other countries and earlier eras. Our American focus is partly a matter of convenience; data and social science on U.S. immigration is relatively abundant. But given its long history of near-open borders, and ongoing role as the world's leading superpower, the U.S. case is also especially relevant and enlightening.

\section{The World Is Far From Open Borders}

How far are we today from open borders? Very. Let's look at the question from three angles: the letter of the law, how much migrants sacrifice to evade the law, and how many people want to move but cannot. Precisely because the world today is remote from open borders, all numbers are crude guesses. But they help us appreciate the radical nature of open borders, or, more precisely, the radical extent to which closed borders 
distort global society and destroy freedom and economic value.

Let's begin with the law. By First World standards, United States immigration laws are fairly liberal. Still, the only routes for legal immigration are family reunification, high skill, refugee or asylum status, and the diversity lottery. Typical family reunification wait times run 7-12 years, and around two decades for Mexicans. ${ }^{2}$ Employment-based visa requirements are stringent: To apply, you need extraordinary ability, distinguished accomplishment that requires at least a postgraduate degree, sponsorship by a U.S. multinational, or $\$ 500,000$ to invest. $^{3}$ High-skilled workers can also try for a nonimmigrant $\mathrm{H}-1 \mathrm{~B}$ visa that allows a transition to permanent residency. This category is so competitive that the annual application quota normally fills in ten days. ${ }^{4}$ The U.S. grants refugee or asylum status to about 50,000 people a year, with a 2012 ceiling of $76,000 .^{5}$ Winning the diversity lottery, finally, is as improbable as it sounds: In 2008, 13.6 million people applied for 50,000 slots. ${ }^{6}$ In addition, some low-skilled workers get $\mathrm{H}-2 \mathrm{~A}$ and $\mathrm{H}-$ 2B visas, but these are hard to get, quick to expire, and cannot be converted to long-term residency.

In sum, the U.S. offers no path for the typical world resident to move long-term, and few options for temporary work. Even temporary visits are hard to arrange, because applicants are, as a matter of U.S. policy, denied if they fail to convince their consular officer that they do not intend to migrate long-term. ${ }^{7}$ As a result, many prospective migrants cross borders illegally or overstay temporary visas. The U.S. currently has 11-13 million illegal immigrants, about a third of its foreign-born population and about $4 \%$ of the total population. ${ }^{8}$ 
How much do these laws matter? Look at the black market prices poor migrants eagerly pay to hop to the border. Smuggler fees from Mexico to the U.S. are now about $\$ 4000-$ four years' income for a typical farm laborer in Mexico. ${ }^{9}$ Prices for more distant countries are predictably higher. A median-income Indian would need to save all his income for over a decade to pay the $\$ 60,000$ smugglers currently charge for illegal transport to the United States. ${ }^{10}$ High though they are, fees underestimate foreigners' commitment to moving. Migrants along the Mexico-U.S. border brave a difficult trek through a hot desert, migrants from Africa to Europe sail on rickety boats, and bordercrossers to South Africa risk getting eaten by lions. ${ }^{11}$

After full deregulation, smuggling fees and the attendant dangers would all but disappear. How many people would choose to relocate? Gallup has conducted worldwide polls since 2010 asking adults whether they would move to another country immediately if allowed. Over 600 million adults $-14 \%$ of the world adult population - wish to permanently move to another country. Over a billion want to seek temporary work abroad. ${ }^{12}$ For comparison, 232 million people currently live outside their country of birth. ${ }^{13}$ The United States is the first-choice destination for over 100 million adults. ${ }^{14}$ Gallup has used these polls to estimate population gain and loss for each country if everyone migrated to their first-choice destination. The effects are huge: Haiti would lose half its population. Australia, Singapore, and New Zealand's would more than double. Even the United States, the world's third most populous country, would see population increase by $60 \% .^{15}$

This does not mean that 200 million immigrants would arrive tomorrow if the United 
States opened its border today. Migrants face a series of bottlenecks. Markets need time to respond to the vast increase in demand for transportation, housing, and jobs. The more enduring bottlenecks, though, are cultural and linguistic. Spain is a more popular migrant destination than Germany because of the global Spanish-speaking population, and Saudi Arabia is a top choice for potential migrants because of its religious importance for Muslims worldwide. Even under open borders, people rarely move to a new country unless that country already has a substantial "diaspora" - a subculture that shares their culture and language.

How do diasporas work ${ }^{16}$ Migration rates between culturally and linguistically disjoint regions start low. Over time, though, buzz builds - and migration snowballs. The first wave sends good news: "We're prospering." The second wave sends better news: "We're prospering, and we're starting to have our own community." The third wave sends better news still: "We're prospering, and our community is flourishing." When the United States opened its border with Puerto Rico in 1904, for instance, the flow was almost invisible. Between 1900 and 1910, Puerto Rico's net emigration was only two thousand souls. Yet decade by decade, Puerto Ricans kept coming - and stateside Puerto Ricans felt increasingly at home. By 2000, there were more Puerto Ricans in the United States than there were in Puerto Rico. ${ }^{17}$

As of 2010, 29\% of foreign-born Americans hailed from Mexico, 24\% from the rest of Latin America, 28\% from Asia, 12\% from Europe, 4\% from Africa, 2\% from North America, and $1 \%$ from elsewhere. ${ }^{18}$ The most reasonable forecast, then, is that open borders would swiftly lead to a large increase in Latin American - and especially 
Mexican - immigration. Their diasporas - and families eager to help - are already here. In the medium term, we should expect the initially smaller diasporas of populous China and India to swell. Given the tiny African immigrant population, and their cultural and linguistic distance from African Americans, migration from Africa's rapidly-growing population will probably start out very low - but end up very high.

Until the 1920s, the United States retained nearly open borders. Few dispute that mass migration played a key role in America's $19^{\text {th }}$-century economic miracle. Some even argue that near-free migration outweighed, and thus masked, the negative effects of late $19^{\text {th }}$-century trade restrictions. ${ }^{19}$ Synergies continued in the early $20^{\text {th }}$ century: mass manufacturing industries, such as Detroit's auto industry, benefited from a large and mobile population, including many recent migrants and children of migrants. ${ }^{20}$

Still, by modern standards, migration during the open borders era remained moderate. The peak foreign-born proportion in 1910 was $15 \%$, comparable to $13 \%$ today. ${ }^{21}$ If the American border were re-opened, we should expect larger, faster changes - diaspora dynamics notwithstanding. Transportation is far cheaper and safer, making long-distance migration practical for the poorest and most remote populations. Communication is vastly better, allowing migrants to keep in touch with friends and family - and word of opportunities to spread far and wide. Culture has globalized. Hundreds of millions of prospective migrants are "pre-assimilated" - fluent in English and avid consumers of American periodicals, television, and movies. The bottom line is that open borders could easily double the U.S. population in a matter of decades. 


\section{How Open Borders Would Change the World}

For all its radicalism, open borders' main effects are fairly well-understood. Open borders would dramatically increase global production. It would drastically reduce global poverty and global inequality. At the same time, open borders would make the remaining poverty and inequality much more visible for current residents of the First World. On other important dimensions - especially budgets, politics, and crime - we should expect no more than moderate changes for good or ill. Let us consider each effect in turn.

Effect on global production. Why does the average American earn so much more than the average Nigerian? Part of the reason is that the average American worker has better skills. The rest of the reason, though, is that the American economy makes better use of whatever skills a worker happens to have. Researchers who disentangle these two effects find the latter accounts for almost all of the global pay gap: being in America is much more important than being American. Moving unskilled workers from Mexico to the United States raises their pay by about $150 \%$. Moving unskilled workers from Nigeria to the United States raises their pay by over $1000 \% .^{22}$ The productivity gain is most visible in agriculture or manufacturing: An unskilled Mexican farmer grows far more food in America than in Mexico. But the gain is equally real in services. A Mexican barber produces more economic value in America because affluent Americans are willing to pay much more for haircuts than poor Mexicans.

Once you grasp the massive effect of location on worker productivity, the economic case for open borders swiftly follows. Global living standards depend on global production. 
Immigration restrictions trap labor in unproductive locations, stunting output. Open borders, in contrast, let everyone on earth move wherever their labor is most productive. Making Nigerians stay in Nigeria is as economically senseless as making farmers plant in Antarctica.

Open borders will thus grow the world economy. By how much? The most serious review of the academic evidence concludes that unrestricted migration would roughly double global GDP, with estimates of the gain ranging from $+67 \%$ to $+147 \%$. $^{23}$ In other words, existing regulations stunt the world's output at roughly half its free-migration level. These magnitudes are staggering, but hardly surprising. Labor is the world's most valuable commodity - yet thanks to strict immigration regulation, most of it goes to waste.

What would this wealth explosion look like? Destination countries for migrants would experience frenetic economic growth - a First World version of the sustained booms China and India enjoyed in recent decades. Hundreds of millions of Chinese and Indians have already moved in response to rising urban wages. China's urbanization rate rose from $18 \%$ in 1976 to $52 \%$ today. Massive migration has turned villages to towns and towns to megacities. By 2025, China will have a billion people living in cities, with 23 cities of over five million and 221 cities of over 1 million (compared to 35 such cities in Europe). ${ }^{24}$ India's 2001 census estimated that 191 million people $-19 \%$ of the country were long-distance internal migrants. ${ }^{25}$ India's urban population will soar from 340 million in 2008 to 590 million in $2030 .^{26}$ 
The flip side is that origin countries will swiftly depopulate. Over a generation or two, poor countries could easily lose half their people - and more than half of their most skilled and ambitious workers. But this is no more tragic than poor villagers exiting the backwaters of China and India. Development is ultimately about people, not places. ${ }^{27}$ And non-migrants benefit, too. Remittances - which already far exceed the flow of foreign aid - start coming home almost immediately. ${ }^{28}$ Before long, successful immigrants start using their newfound business connections to develop their mother countries. $^{29}$ Puerto Rico provides an excellent illustration. Over half of Puerto Ricans live abroad, but Puerto Ricans who stayed behind now enjoy a First World standard of living. 30

In the short run, open borders would massively reduce the capital/labor ratio in destination countries, and raise it in origin countries. The First World would see a large expansion in the low-skilled service sector, including childcare, cleaning, and driving, and a switch to more labor-intensive farming and construction. The U.S. could also easily become a hub for the sort of labor-intensive manufacturing currently done in China, with natives taking on higher-paying supervisory roles.

Over the long run, as usual, we should expect capital accumulation to rise with labor supply. ${ }^{31}$ How long would workers have to wait for "the long run" to arrive? The Israeli experience is instructive despite its peculiarities. The Law of Return, valid since 1950, grants every Jew the right to settle in Israel. ${ }^{32}$ Israel's 1989 population was 4.6 million. Between 1990 and 1997, 700,000 immigrants from the Soviet Union showed up - about half during a two-year period. In the short-run, this seemed to depress native wages 
about 5\%. Yet by 1997, native wages were back at their expected pre-immigration level. ${ }^{33}$

How will the oversize fruits of open borders be distributed? Researchers often focus on the change in the capital/labor ratio, and conclude that open borders enriches First World capital and Third World labor at the expense of Third World capital and First World labor. Estimates of the size of the effect on First World labor are small; according to Kerr and Kerr's state-of-the-art literature survey, a 10 percentage-point increase in the immigrant share of the labor force reduces native wages by a mere $1 \% .{ }^{34}$ Furthermore, the net effect for First World workers is unclear because labor is not their only asset. Immigration sharply increases real estate prices, so any home-owning worker would enjoy a massive capital gain. ${ }^{35}$ Furthermore, every worker with a retirement fund is, in part, a capitalist.

More sophisticated analysts point out that immigration can raise First World wages, too. In the real world, there are many distinct kinds of labor. Native workers suffer when immigrants have competing skills, but gain when immigrants have complementary skills. This chapter's authors, for example, are both Ph.D.s. When foreign Ph.D.s enter the U.S. labor market, we suffer. The immigration of waiters, in contrast, enriches us. We are waiters' customers, not their competitors.

Under open borders, immigrant and native skill sets will drastically diverge. Compared to natives, most prospective immigrants are very poorly educated. Rather than losing their jobs to immigrants, natives will likely become their supervisors and managers. Between 1980 and 2000, U.S. immigrants tended to be either low-skilled or high-skilled. 
Even relatively pessimistic economists confirm the expected result: Immigration hurt low-skilled and high-skilled natives, but raised wages for mid-skilled natives. ${ }^{36}$ Other observers note that formal education is a crude measure of skill. Most obviously, natives speak better English than equally educated foreigners. Accounting for these subtleties, recent immigration seems to slightly raise average natives wages. ${ }^{37}$

Some development economists worry that liberalizing migration retards the Third World's economic growth and political reform by siphoning off their best and brightest citizens. But this "brain drain" is largely an artifact of current skill-based immigration policies. Under open borders, ditch diggers are as free to migrate as computer programmers. Even under the status quo, though, so-called brain drain has offsetting benefits for those left behind. Skilled immigrants often return with valuable skills, investment capital, and business connections. Furthermore, opportunities for high-skilled emigration spur skill acquisition. Empirically, such incentives look strong enough to make the average non-migrant more skillful. ${ }^{38}$

Migration doesn't just make migrants more productive; it makes them more innovative. Silicon Valley is a breeding-ground for world-changing technology. If Silicon Valley's immigrants had stayed home, it is hard to see how they could have created more than a fraction of what they did in the U.S. ${ }^{39}$ Since new ideas anywhere now rapidly help people everywhere, moving the best and brightest to centers of global innovation indirectly enriches source countries, too. Analyses of innovation in the $19^{\text {th }}$ century United States paint similar conclusions. ${ }^{40}$ 
Effect on global poverty and inequality. Rural-to-urban migration within China, India, and other low-income countries hasn't just been a key pillar of expanding per-capita output. Migration-fueled growth has also sharply reduced global poverty and global inequality. Sala-i-Martin (2006) uses international data to construct the World Income Distribution for $1970-2000 .{ }^{41}$ During this period, the share of the world living in poverty drastically fell. Raising the poverty line naturally raises measured poverty, but the fact of decline is robust. ${ }^{42}$ Subsequent research confirms that these beneficent trends are continuing. ${ }^{43}$ Open borders could well cast the decisive blow against human poverty, even if the estimate of the impact of open borders on global production is significantly overstated. $^{44}$

Migration-fueled economic growth around the world has also steadily reduced global inequality. From 1970-2000, the World Income Distribution became more equal by eight distinct metrics. ${ }^{45}$ How is this possible given the sharp rise in inequality within countries? Simple: In the modern world, about two-thirds of global inequality reflects inequality between countries rather within them. ${ }^{46}$

Economically speaking, open borders is familiar rural-to-urban migration writ large. When poor people relocate from low-productivity to high-productivity areas, they simultaneously enrich the world, escape poverty, and equalize the income distribution. The key difference: Open borders will lead to larger, quicker progress than traditional rural-to-urban migration because international gaps dwarf intranational gaps. Due to diaspora dynamics, we should not expect international inequality to vanish overnight. But given the enormity of the wage gains migrants experience, progress will start strong 
and steadily accelerate.

Effect on the visibility of poverty and inequality. Migrating to a rich country is a great way to escape absolute poverty. When low-skilled immigrants arrive, however, most will remain relatively poor by the standards of their new country. Given expected flows, most natives will soon encounter relatively poor foreigners on a daily basis. ${ }^{47}$

The visibility of poverty and inequality is likely to be unsettling, particularly if government policies restrict newly arrived migrants' access to the welfare state. The shift to labor-intensive occupations will make developed countries look more primitive. Shantytowns may emerge. Some natives will react by helping migrants learn the language, find jobs, and adjust to their new societies. Others will resent new arrivals and pine for the good old days when low-skilled immigration was but a trickle. Before long, however, most natives will, like the Third World middle class, simply learn to tolerate the sight of poverty and inequality. From immigrants' point of view, callous natives are preferable to narcissistic altruists who minimize their feelings of pity by keeping poor foreigners out of the country.

Effect on the budget. Immigration's fiscal effects are uncertain in sign, moderate in size, and small compared to the economic effects. ${ }^{48}$ Overall, the net fiscal gain from migration is near-zero for OECD countries, with estimates ranging from modestly negative to modestly positive. Adult immigrants are normally educated at their home country's expense, making them a prima facie good deal for receiving countries. The foreign-born typically use more welfare. At least in the United States, however, the foreign-born poor, 
use less welfare than the native poor. This is partly due to restrictions on welfare eligibility for migrants, suggesting that further tightening would make migration a clear fiscal plus. ${ }^{49}$

Can we generalize from the present to the world of open borders? The main concern: Net fiscal effects vary widely by skill. For the U.S., Storesletten (2000) calculates a \$96,000 net fiscal benefit for highly educated immigrants and a $\$ 36,000$ net fiscal cost for uneducated immigrants, versus a net cost of $\$ 80,000$ for the typical native. However, these estimates seem pessimistic across the board; Wolf et al (2011) find that the average newborn American native has a net fiscal benefit of $\$ 83,000$. On balance, there is no solid reason to expect the average immigrant under open borders to be a fiscal drain. However, since immigration will sharply increase, the total fiscal effect could end up being highly positive or highly negative.

Effect on crime. Empirical work on migration and crime focuses on receiving countries. The big result: open borders may well decrease crime rates in many receiving countries, and is at any rate unlikely to cause crime rates to rise sharply. In the U.S., the foreignborn have one-fifth the native incarceration rate. ${ }^{50}$ This is not just a reflection of American criminality. Japan has one of the lowest crime rates in the world, but its immigrants are even more law-abiding than the rest of the population. ${ }^{51}$ While many blame South Africa's crime woes on the end of apartheid's internal migration restrictions, the evidence suggests otherwise. Its homicide rate, though high, has dropped steadily post-1994..$^{52}$ 
What about crime in sending countries? Open borders is a powerful lifeline for the potential victims of genocide, ethnic cleansing, and other war crimes. Imagine how many victims of the Holocaust would have survived if the United States had open borders during the 1930s. Safety, like development, is ultimately about people, not places. Rising per-capita income also gives potential criminals more to lose. Research is scarce, but there are good reasons to expect migration to reduce non-migrants' victimization risk.

Effects on politics. Under democracy, the quality of policy depends on the quality of the electorate. Wise voting leads to good policies, foolish voting to bad policies. ${ }^{53}$ In absolute terms, most voters look quite foolish. They're not just poorly informed; they're predictably irrational. ${ }^{54}$ It is possible, however, that native voters are bad, but immigrant voters are even worse. Critics who raise this concern usually equate free-market policies with wisdom, and worry about foreigners' anti-market perspective. The U.S.-based General Social Survey (GSS), inaugurated in 1972 and still running, is probably the single best source of information on these matters. What does it tell us?

By most measures, foreigners are indeed more anti-market than native-born Americans. ${ }^{55}$ Yet the size of the foreign-native gap is moderate. The foreign-born are .11 standard deviations more liberal than natives. ${ }^{56}$ The GSS asks, "If the government had a choice between reducing taxes or spending more on social programs like health care, social security, and unemployment benefits, which do you think it should do?" The foreignborn are 8 percentage-points more likely to say "spend more on social programs." 57 The GSS also features nine questions asking, "On the whole, do you think it should or should not be the government's responsibility to..." regulate and redistribute in various ways. ${ }^{58}$ 
Overall, the foreign-born are .35 standard deviations more favorable toward big government. Yet there is one major issue where the foreign-born are .76 standard deviations more opposed to government regulation: immigration itself. ${ }^{59}$

Foreigners tend to combine their economic liberalism with social conservatism. The GSS features five questions about free speech for unpopular minorities. ${ }^{60}$ Overall, the foreignborn are .19 standard deviations less supportive of free speech. Less-educated foreigners - like less-educated natives - are especially authoritarian. Foreign-born high school dropouts are .81 standard deviations more in favor of regulation and redistribution, and .59 standard deviations less supportive of free speech.

On reflection, though, raw public opinion data makes immigration look a lot more politically dangerous than it really is. Open borders gives everyone the right to live and work where he likes, sharply reducing the incentive to become a citizen. Legal U.S. residents have to wait five years before they can even apply for citizenship. ${ }^{61}$ When immigrants finally gain the right to vote, they often fail to show up: Migrants and their descendants have lower voter turnout than natives. ${ }^{62}$ The worryingly authoritarian lesseducated foreigners are especially abstentious. In the 2008 presidential election, for example, only $25 \%$ of eligible foreign-born high school dropouts chose to vote. ${ }^{63}$ Emerging evidence in political science suggests, moreover, that low-income citizens have little political influence anyway. When high- and low-income Americans disagree, politicians cater to high-income preferences. ${ }^{64}$

Finally, a large literature finds that the very presence of immigrants sours natives on the 
welfare state. ${ }^{65}$ Voters are happy to support generous government benefits for their own kind, but not outsiders. Indeed, the ethnic diversity of the United States is a standard explanation for its relatively small welfare state. ${ }^{66}$ The net political effect of immigration is therefore unclear. When social scientists directly measure the effect of immigration on the size of government, most detect little effect. ${ }^{67}$ A particularly thorough recent study finds that immigration fails to noticeably change U.S. states' spending on TANF/AFDC, education, or health. ${ }^{68}$

\section{Open Borders: A Case of Moral Consilience}

Predictions about the effects of open borders are far from certain. No major country has experienced anything close to open borders for almost a century, making extrapolation difficult. One effect, however, is clear: Open borders will drastically increase global production. This transformation of the world economy makes other large changes highly likely: Sharp reductions in global poverty and inequality, combined with greater visibility of the poverty and inequality that remain. The effects on other dimensions - budgets, crime, and politics - are less clear, but standard estimates of the global effects range from mildly negative to mildly positive. Even if you take strong issue with some of our empirics, the overall conclusion that open borders would be a boon to the world is hard to dispute.

Does this mean that countries are morally obliged to open their borders? In this section, we argue that every prominent moral view yields the same answer: Yes. Utilitarianism, efficiency, egalitarianism, human capabilities, libertarianism, meritocracy, and Christianity all recommend open borders. ${ }^{69}$ For moral theories like libertarianism that 
prioritize individual rights, the recommendation is clear-cut. For more pragmatic theories, the enormous - and pro-poor - economic gains are almost equally decisive. Doubling GDP can outweigh a lot of sins. Indeed, even moral theories like citizenism that place little or no weight on foreigners' well-being endorse open borders when packaged with pro-native taxes and transfers.

The utilitarian case for open borders. The utilitarian case for open borders is straightforward: Open borders swiftly and reliably enriches mankind, especially the global poor. Instead of relying on often corrupt government-to-government transfers, open borders allows everyone on earth to enrich themselves by heading wherever their talents are most valuable. As long as the rise in global GDP exceeds 50\%, it is hard to see any offsetting harms in the same ballpark. Even in an unlikely scenario where open borders destroys First World welfare states, the benefits for hundreds of millions of absolutely poor foreigners clearly outweigh the costs for tens of millions of relatively poor natives.

The efficiency case for open borders. Economic efficiency measures costs and benefits purely by willingness to pay. ${ }^{70}$ When is relocation efficiency-enhancing? Whenever it raises a worker's productivity by more than the material and psychological cost of moving. The whole point of immigration restrictions, though, is to ban immigration that passes this efficiency test. Unlike utilitarianism, economic efficiency counts the preferences of the rich and poor equally; an extra dollar in Haitian hands counts no more than an extra dollar in American hands. The apostle of economic efficiency will therefore disregard the pro-poor distributional effects of free migration, and treat the extra visibility 
of poverty as a serious cost. Still, given the huge effect on global output, the efficiency case for open borders is solid.

The egalitarian case for open borders. Migration restrictions drastically and deliberately reduce equality of both opportunity and result. The effect on equality of opportunity is almost definitional. Laws exclude the global poor from the best labor markets because they proverbially "chose the wrong parents." The effect on equality of result is more empirical, but almost as clear. To repeat: In the modern world, country of origin accounts for about two-thirds of all income inequality. ${ }^{71}$ Without immigration laws, unskilled labor in the Third World could not durably earn a fifth or a tenth as much as unskilled labor in the First World. Even if open borders miraculously toppled First World welfare systems, the genuine egalitarian should focus on the shrinking gap between absolutely rich natives and absolutely poor foreigners, not the growing gap between the world's absolutely rich natives and relatively poor natives. The Rawlsian ethical framework, which accepts inequality if and only if it benefits the "worst-off group," also implies support for open borders. ${ }^{72}$ While egalitarians who take "brain drain" seriously could condemn First World countries for poaching the Third World's best and brightest, open borders largely dissolves such complaints by making illiterates as free to migrate as Nobel laureates. It's not surprising that many egalitarian-minded philosophers who have given consideration to the questions surrounding open borders have come to support open borders. $^{73}$

The human capabilities case for open borders. The human capabilities approach pioneered by Martha Nussbaum and Amartya Sen stresses that all individuals should have 
realistic opportunities to fulfill their potential. ${ }^{74}$ Closed borders willfully deletes the global poor's best options for escaping poverty and living fulfilling lives. Even the wellto-do may be unable to reach their full potential because border restrictions prevent them from moving to a dream job or uniting their extended family. Supporters of the human capabilities approach unsurprisingly argue for fewer migration restrictions. ${ }^{75}$

The libertarian case for open borders. The absolutist libertarian case for open borders is clear-cut: Immigration restrictions impermissibly restrict capitalist acts between consenting adults. Neither government nor "society" has any right to prevent employers, landlords, or merchants from trading with foreigners. All analysis of immigration's social effects is beside the point. Proponents of a wide range of libertarian and freedomoriented ideologies, including Ayn Rand and Murray Rothbard have made principled arguments for open borders along these lines. ${ }^{76}$

What about the more moderate view that we should adhere to libertarian principles unless doing so is awful for human well-being? This too leads to staunch support for open borders. Empirically, open borders looks like a great deal for the world, so there is no rights-utility trade-off to resolve. ${ }^{77}$ Unlike the utilitarian, though, the moderate libertarian has to support free migration even if its vast benefits turn out to be entirely illusory. As long as the aggregate effects of open borders are better than awful, the libertarian cannot in good conscience compromise the fundamental human right to accept a job offer from a willing employer. Even if immigration predictably led to a large expansion of the welfare state, the moderate libertarian would have to weigh freedom from taxation against freedom of movement and trade. For the moderate libertarian, excluding foreigners who 
might vote for statist policies is less justified than exiling natives who do vote for statist policies.

The meritocratic case for open borders. Free labor markets do not guarantee that the best workers will receive the best jobs and pay. But immigration restrictions are consciously designed to protect native workers from more qualified and motivated foreigners. Meritocratic norms say, "Hire the best person." Immigration laws say, "No, you are only free to hire the best citizen." The status quo does not merely allow discrimination on the basis of nationality; it mandates such discrimination. Anyone who accepts merit as a moral imperative or discrimination as a grave evil should be strongly predisposed to open borders.

Meritocratic critics of immigration occasionally argue that the impoverished inhabitants of the Third World morally deserve their fate. Their suffering is fitting punishment for creating such dysfunctional societies. But what precisely should the typical low-skilled Third World worker have done differently? One vote is astronomically unlikely to change policy even in clean democracies, much less the corrupt democracies and dictatorships that most of the Third World endures. And how can we condemn a semiliterate worker for failing to fix his polity when the world's brightest minds are at a loss for answers? You could blame the ignorant voter for failing to abstain, but lifelong, hereditary exclusion from the world's best labor markets seems a draconian punishment for voting the wrong way. ${ }^{78}$ In any case, contrary to all meritocratic principles, immigration laws punish indiscriminately. Residents of the Third World face lifelong, hereditary exclusion no matter how they vote. 
The Christian case for open borders. The New Testament and broader Christian tradition are a natural fit with open borders. ${ }^{79}$ Both emphasize our common humanity and preach strong obligations to welcome and support to the needy. Consider, "I was a stranger and you took me in," (Matthew 25:35), "There is neither Jew nor Greek, slave nor free, male nor female, for you are all one in Christ Jesus" (Galatians 3:28), and "When you give a banquet, invite the poor, the crippled, the lame, the blind, and you will be blessed. Although they cannot repay you, you will be repaid at the resurrection of the righteous" (Luke 14:12-14). Even the Old Testament repeatedly urges just treatment of foreigners: "Do not mistreat or oppress a foreigner, for you were foreigners in Egypt" (Exodus 22:21) and "You must have the same regulations for both the foreigner and the nativeborn" (Numbers 9:14). Open borders is not charity. But even if it were, Christians seem obliged to support it.

The citizenist case for open borders. Many proponents of immigration restrictions argue that immigration policy should put little weight on the welfare of foreigners. Instead, they accept what Steve Sailer calls "citizenism": governments should focus on promoting the interests of current citizens and their descendants. ${ }^{80}$ This moral position has been embraced by a wide range of critics of open borders, including Center for Immigration Studies director Mark Krikorian, National Review's Reihan Salam, and Demos director David Goodhart.

Citizenists often grant the utilitarian case for open borders, then insist that almost all of the economic benefits go to foreigners. Facts aside, their reaction is deeply uncreative. A 
thoughtful citizenist should not say, "Open borders would make foreigners trillions of dollars richer. So what?" Instead, he should say, "Trillions of dollars of wealth are on the table. How can my countrymen get a hefty piece of the action?" Modern governments routinely use taxes and transfers to redistribute from young to old and rich to poor. Why not use the same policy tools to redistribute from foreign to native? Charge immigrants extra taxes. Further restrict their access to government benefits. Then use the proceeds to cut taxes and increase benefits for natives. What could be simpler? From a citizenist point of view, such policies are perfectly "fair"; government is supposed to discriminate on natives' behalf. Less parochial moral philosophies could protest the unfairness, but they should concede that open borders tempered by pro-native redistribution is far less unfair to foreigners than the status quo.

\section{Response to Objections}

Open borders speaks to every major moral outlook. Given the evidence, you would expect the approach to enjoy widespread support. Yet in practice, support for open borders is rare. The World Values Survey asked the people of forty eight nations their views on migration. In most countries surveyed, under $10 \%$ said, "Let anyone come." 81 Why is open borders so unpopular?

Most of the opposition, in our view, reflects unthinking xenophobia. Nevertheless, the majority of people the authors consider reasonable have yet to embrace open borders. Every major moral viewpoint implies open borders given our empirical claims, so we suspect that reasonable skeptics find our empirics unsatisfactory. In this section, we try 
to identify and answer their overarching complaints.

Open borders is far out of sample. All of our claims about the effects of open borders rely on (a) experience with open borders in the distant past, or (b) experience with relatively high immigration in the recent past. Both forms of evidence are problematic. Transportation and communication have drastically improved over the past century, so open borders today could be very different from open borders a century ago. Social changes often have non-linear effects, so open borders could be bad even though moderate immigration is good.

This critique has a kernel of truth: Each of our forecasts should have wide confidence intervals. For any given outcome, the true effect of open borders is likely to be far above or below its expected value. To estimate those expected values, however, we must rely on past experience. We can acknowledge wide confidence intervals, yet still safely predict that open borders will be better than the status quo, as long as some key expected values are enormously favorable, and the rest are ambiguous.

This is precisely what the evidence shows. The expected impacts on global production, poverty, and inequality are enormously favorable. The expected impacts on the budget, crime, and politics are ambiguous. Should all of these estimates prove too sanguine, though, open borders likely remains a good deal. Suppose standard estimates of the effect of open borders on global output, poverty, and inequality are overstated by a factor of five. In absolute terms, that is still a present discounted value of tens of trillions of dollars. To offset a gain of this scale, the combined budgetary, crime, and political effects 
of open borders would have to be horrific.

I'm still really worried about $X$. While research on open borders is growing, many important facets remain unexplored. Research on political ramifications is especially underdeveloped. As a result, a fair-minded reader might harbor serious concerns about some of open borders' effects.

Part of our answer, again, is that the estimated benefits of open borders on production, poverty, and inequality are so enormous that they provide a large margin of error. But we can do better than this. Let us concede for the sake of argument that - holding all other policies fixed - open borders would impoverish low-skilled natives, sharply raise crime rates, break the budget, destroy the welfare state, or unleash populist policies. Migration restrictions would remain a needlessly cruel and costly way to handle the critics' concern. Why? Because each of these problems has a "keyhole solution" - a remedy tailored to handle the alleged problem while leaving the world's borders open to peaceful migration. As Tim Harford explains:

Keyhole surgery techniques allow surgeons to operate without making large incisions, minimizing the risk of complications and side effects. Economists often advocate a similar strategy when trying to fix a policy problem: target the problem as closely as possible rather than attempting something a little more drastic. ${ }^{82}$

Instead of rejecting open borders, then, critics should embrace a package of open borders combined with other policy reforms. ${ }^{83}$ Suppose you think that open borders would be awful for low-skilled natives. Once you grant immigration's overall economic benefits, the logical solution is not exclusion, but redistribution. Government could impose immigrant entry fees and surtaxes, then use the proceeds to compensate native workers 
with a monthly check, a lower marginal tax rate, a payroll tax exemption, or a bigger Earned Income Tax Credit. Analogous policies could be used to deter crime; immigrants could post a "crime bond" when they enter the country, knowing that they forfeit the bond if convicted of an offense.

If you fear immigrants' fiscal effect, the natural solution is, in the words of Alex Nowrasteh and Sophie Cole (2013), to "build a wall around the welfare state, instead of the country." In short, selective austerity. Government could give immigrants reduced benefits, make them ineligible for specific programs, or exclude them entirely. This selective austerity could last for a decade; it could stand until the immigrant pays $\$ 100,000$ in taxes; it could be lifelong. The fiscal burden of immigration is not a law of nature. It the result of deliberate - and malleable - policy. By keeping fiscal burdens under control, and giving natives preferential access, selective austerity also helps preserve the welfare state as we know it. Current beneficiaries don't have to worry about being crowded out, and voters won't be alienated by the thought that out-groups are feeding off their generosity.

Controlling the political effects of immigration is especially straightforward. If you really worry that immigrants vote the wrong way, don't let them vote. In the current regime, permanent residents already wait many years for citizenship. The delay could easily be extended - or made permanent. Alternately, immigrants might gain voting rights after paying $\$ 100,000$ in taxes. While there is no solid reason to expect immigrants to vote for disastrous policies, it is far better to let them in and deny them the vote than exclude them as an act of pre-emptive political self-defense. 
Keyhole solutions are unrealistic. Keyhole solutions rarely win over critics of immigration. While they would work in theory, they are politically impossible - mere daydreams unworthy of serious consideration. Strangely, though, the same critics willingly debate a far more fantastic proposal: open borders itself. If you can imagine the political landscape changing enough to make global open borders a reality, what is so implausible about pro-native redistribution, selective austerity, or voting limits?

The deeper problem with critics' incredulity, though, is that countless "keyhole solutions" already exist in the United States and around the world. Legal immigrants to the United States face deportation for even minor non-violent infractions such as marijuana possession. ${ }^{84}$ China's hukou system for intranational residency restricts internal migrants' rights to collect government benefits and vote. ${ }^{85}$ In Singapore and the UAE, guest workers have very limited legal rights. ${ }^{86}$ Even Sweden, a country with strong pro-migrant sentiment, makes migrants wait five years for citizenship. ${ }^{87}$ Open borders is perhaps an impossible dream, but keyhole solutions are already a concrete reality.

We should apply the precautionary principle. Open borders is a radical proposal. Its consequences remain speculative. No matter how promising the proposal looks, shouldn't we move toward open borders gradually, learning more and more about its farreaching consequences as we go? For all their flaws, modern First World societies remain the pinnacles of human civilization. Hundreds of millions of people enjoy lives that kings of old could scarcely imagine. This seems like a perfect time to apply the "precautionary principle" - to wait for definitive proof that open borders would succeed 
instead of betting all our achievements on a mere idea. ${ }^{88}$

The precautionary principle also implies, however, that a long list of historical injustices should have been phased out much more gradually. In 1860, the effects of abolishing U.S. slavery were unforeseeable. Who could accurately predict the results of releasing millions of illiterate slaves on the economy, crime, politics, or social stability itself? While the British had previously ended slavery in their colonies, they were not putting their home country at risk. In 1960, the effects of suddenly ending U.S. segregation were similarly hazy. The nation's nineteen million blacks had never been treated equally before. Or take the breakneck dismantling of South African apartheid in the early 1990s. Nearby Angola, Mozambique, and Zimbabwe had virtually collapsed after the end of white rule, but most observers still saw cautious phase-out of South African apartheid as moral cowardice.

The lesson: The precautionary principle may be a good rule when weighing a token gain against a fuzzy risk of social collapse, but not when the status quo impoverishes billions by prohibiting peaceful movement and trade. Yes, the current residents of the First World have wonderful lives. But the rest of the world should not have to endure preventive detention for the peace of mind of the fortunate few.

Why has nobody tried open borders? While borders were nearly open until the early $20^{\text {th }}$ century, no major country has had open borders since then, and none looks poised to try anytime soon. If open borders is such a great idea, why has nobody tried it? Even if political leaders in individual countries are irrational or face specific impediments to 
opening borders, the fact that no country has opened its borders seems troubling.

This is a strong objection for readers who doubt the wisdom of all policies that no country accepts. In our view, though, many untried policies are clearly superior to the status quo. No country has complete free trade, raises most of its revenue from taxes on negative externalities, or permits a free market in human organs. If one accepts these or similar examples, ubiquitous immigration restrictions are hardly surprising. The best general explanation, in our view, is that human beings around the world have pronounced anti-market and anti-foreign biases. While the intensity of these biases vary from culture to culture, they are strong everywhere. ${ }^{89}$ Keyhole solutions, similarly, are unpopular because human beings care far more about visible harm than actual harm. ${ }^{90}$

\section{Conclusion}

While we don't know exactly what open borders would do, that's the same as saying we don't know exactly how much damage the status quo inflicts. In expectation, the damage is massive. It is all too easy for us - particularly comfortable First Worlders - to forget the moral urgency of freedom of movement. Under the status quo, tens of millions around the globe live as unauthorized migrants, fearing the law enforcement that is supposed to protect them. And they're the lucky ones. Hundreds of millions want to seek a better life in another land, but find the black market back door too costly and too scary. Border controls tear families apart and crush countless dreams of people rich and poor. Are the risks of open borders really dire enough to continue calling foreigners criminals for peacefully moving to opportunity? 
Open borders is radical because the status quo is a radical abridgment of freedom based on an arbitrary distinction, propped up by status quo bias and moral apathy. ${ }^{91}$ In the heyday of American Jim Crow laws and South African apartheid, most people meekly accepted outgroup oppression as the natural state of the world. The same vice plagues the world today: nationalism blinds us to migration restrictions' grave injustice and exorbitant harm. In the $19^{\text {th }}$-century, open borders allowed global freedom, prosperity, opportunity, and equality to advance hand-in-hand. A century later, the promise of open borders is greater than ever. The global poor don't need charity to escape poverty. They have more than enough talent to begin their journey to prosperity once the governments of the world get out of the way.

\section{References}

Alesina, Alberto; Glaeser, Edward; and Sacerdote, Bruce. 2001. "Why Doesn't the U.S. Have a European-Style Welfare State?" Brookings Papers on Economic Activity 2, pp.187-254.

Barro, Robert, and Xavier Sala-i-Martin. 2003. Economic Growth. Cambridge, MA: MIT University Press.

Bohanon, Cecil E. and Van Cott, T. Norman (2005). "Tariffs, Immigration and Economic Insulation: A New View of the U.S. Post-Civil War Era." The Independent Review, (Spring 2005). Available online at http://www.independent.org/publications/tir/article.asp?a=520.

Borjas, George, and Katz, Lawrence (2005) "The Evolution of the Mexican-Born Workforce in the United States." In G. Borjas (ed.) Mexican Immigration to the United States, Chicago: University of Chicago Press, p.49. Available online as NBER Working Paper No. 11281 (issued April 2005) at http://www.nber.org/papers/w11281.

Brennan, Jason. The Ethics of Voting. Princeton University Press (April 3, 2011). ISBN 978-0691144818.

Butcher, Kristin F. and Piehl, Anne Morrison (2007). "Why are Immigrants' Incarceration Rates so Low? Evidence on Selective Immigration, Deterrence, and Deportation." NBER Working Paper No. 13229 (July 2007). Available online at http://www.nber.org/papers/w13229. 
Caplan, Bryan (2007). The Myth of the Rational Voter. Princeton University Press. ISBN 978-0-691-12942-6.

Caplan, Bryan (2012). "Why Should We Restrict Immigration?” Cato Journal, Vol. 32, No. 1 (Winter 2012). Available online at http://www.cato.org/sites/cato.org/files/serials/files/cato-journal/2012/1/cj32n1-2.pdf.

Carens, Joseph (2013). The Ethics of Immigration. Oxford University Press (November 15, 2013). ISBN 978-0199933839.

Chandy, Laurence, and Gertz, Geoffrey. 2011. "Poverty in Numbers: The Changing State of Global Poverty from 2005 to 2015." Global Economy and Development at Brookings. Policy Brief 2011-01. Available online at http://www.brookings.edu/research/papers/2011/01/global-poverty-chandy.

Clemens, Michael, Montenegro. Claudio E., and Pritchett, Lant (2008). "The Place Premium: Wage Differences for Identical Workers across the U.S. Border - Working Paper 148." Available online at http://www.cgdev.org/publication/place-premium-wagedifferences-identical-workers-across-us-border-working-paper-148

Clemens, Michael (2011). "Economics and Emigration: Trillion-Dollar Bills on the Sidewalk?" Journal of Economic Perspectives, Vol. 25, No. 3 (Summer 2011), pp. 83106. Available online at http://pubs.aeaweb.org/doi/pdfplus/10.1257/jep.9.2.23

Collier, Paul (2013). Exodus: How Migration is Changing Our World. Oxford University Press, October 1, 2013. ISBN 978-0195398656.

Dobkin, Donald (2009). "Challenging the Doctrine of Consular Nonreviewability." Georgetown Immigration Law Journal, Vol. 24, pp. 113-146, November 2009. Available online at http://lawprofessors.typepad.com/files/articledobkin1.pdf

Docquier, Frédéric, and Hillel Rapoport. 2012. "Globalization, Brain Drain, and Development." Journal of Economic Literature, 50(3): 681-730.

Doherty, Brian. 2007. Radicals for Capitalism: A Freewheeling History of the Modern American Libertarian Movement. NY: Perseus Books.

Gilens, Martin (2012). Affluence and Influence: Economic Inequality and Political Power in America. Princeton, NJ: Princeton University Press.

Gilens, Martin. 1999. Why Americans Hate Welfare: Race, Media, and the Politics of Anti-Poverty Policy. Chicago: University of Chicago Press.

Gochenour, Zachary, and Alex Nowrasteh (2014). "The Political Externalities of Immigration: Evidence from the United States." Cato Institute Working Paper No. 14, released online January 15, 2014. Available online at 
http://www.cato.org/publications/working-paper/political-externalities-immigrationevidence-united-states

Gonzalez, Libertad, and Ortega, Francesc (2009) "Immigration and Housing Booms: Evidence from Spain.” IZA Discussion Paper No. 4333. Bonn, Germany: Institute for the Study of Labor. Available online at http://ftp.iza.org/dp4333.pdf.

Guest, Robert (2011). Borderless Economics: Chinese Sea Turtles, Indian Fridges and the New Fruits of Global Capitalism. Palgrave Macmillan, November 8, 2011. ISBN 0230113826.

Harford, Tim. 2007. The Undercover Economist. NY: Random House.

Huemer, Michael (2010). "Is There a Right to Immigrate?" Social Theory and Practice, Vol. 36, No. 3, pp. 249-261. Available online at http://spot.colorado.edu/ huemer/immigration.htm.

Karabarbounis, Loukas, and Neiman, Brent (2014). "The Global Decline of the Labor Share." Quarterly Journal of Economics, Vol. 129, pp. 61-103. Earlier version available as NBER Working Paper No. 19136 (issued June 2013) online at http://www.nber.org/papers/w19136

Kennan, John (2013). “Open Borders.” Review of Economic Dynamics 16, pp.L1-L13, available online at http://www.ssc.wisc.edu/ jkennan/research/OpenBorders.pdf.

Kerr, William R. and Kerr, Sari Pekkala (January 2011). Economic Impacts of Immigration: A Survey. NBER Working Paper No. 16736. Available online at http://www.nber.org/papers/w16736.

Khan, B. Zorina and Sokoloff, Kenneth L. (1993). "Schemes of Practical Utility": Entrepreneurship and Innovation Among "Great Inventors" in the United States, 17901865."The Journal of Economic History, Vol. 53, Issue 2 (June 1993), pp. 289-307. Available online at http://dx.doi.org/10.1017/S0022050700012924.

$\mathrm{Ku}$, Leighton, and Bruen, Brian (2013). "Poor Immigrants Use Public Benefits at a Lower Rate than Poor Native-Born Citizens." Cato Economic Development Bulletin No. 17 (March 4, 2013).

Landsburg, Steven. 2012. The Armchair Economist: Economics and Everyday Life. NY: Free Press.

Legrain, Philippe (2007). Immigrants: Your Country Needs Them. Princeton University Press, July 15, 2007. ISBN 978-0691134314.

Machado, Joël, Delogu, Marco, and Docquier, Frédéric (2013). "The Dynamic Implications of Liberalizing Global Migration." Economic Studies Conference, Munich. http://www.cesifo-group.de/portal/page/portal/CFP_CONF/CFP_CONF_2013/Confes13_Poutvaara/Paper/es13_Machado.pdf 
Mayhew, Robert, ed. 2005. Ayn Rand Answers: The Best of Her $Q \& A$. NY: Penguin Books.

Milanovic, Brank. (2012a). "Global Inequality: From Class to Location, from Proletarians to Migrants.” Global Policy 3, pp.125-34.

Milanovic, Branko (2012b). "Global Income Inequality by the Numbers: In History and Now." World Bank Policy Research Working Paper 6259, available online at http://elibrary.worldbank.org/doi/pdf/10.1596/1813-9450-6259.

Nowrasteh, Alex, and Cole, Sophie (2013). "Building a Wall around the Welfare State, Instead of the Country." Cato Institute Policy Analysis \#732 (July 25, 2013). Available online at http://www.cato.org/publications/policy-analysis/building-wall-around-welfarestate-instead-country.

O'Riordan, Timothy, and James Cameron. 1994. Interpreting the Precautionary Principle. London: Cameron May Ltd.

Ottaviano, Gianmarco, and Peri, Giovanni (2012). "Rethinking the Effect of Immigration on Wages." Journal of the European Economic Association 10, pp.195-91. Available online at http://www.nber.org/papers/w12497.

Pashler, Hal (2013). “U. S. Immigrants' Attitudes Towards Libertarian Values.” Available online at http://papers.ssrn.com/sol3/papers.cfm?abstract_id=2234200.

Risse, Matthias (2009). "Immigration, Ethics, and the Capability Approach." Human Development Research Paper (HDRP) Series, Vol. 34, No. 2009 (2009). Available online at http://mpra.ub.uni-muenchen.de/19218/

Rubin, Paul. 2003. "Folk Economics.” Southern Economics Journal 70, pp.157-71.

Saiz, Albert (2003). "Room in the Kitchen for the Melting Pot: Immigration and Rental Prices." The Review of Economics and Statistics, Vol. 85, No. 3 (August 2003), pp. 502521. Available online at http://dx.doi.org/10.1162/003465303322369687.

Saiz, Albert (2007). "Immigration and housing rents in American cities." Journal of Urban Economics, Vol. 61, No. 2, pp. 345-371. Available online at http://dx.doi.org/10.1016/j.jue.2006.07.004.

Sala-i-Martin, Xavier (2006). "The World Distribution of Income: Falling Poverty and... Convergence, Period." Quarterly Journal of Economics, Vol. 121, No. 2, pp. 351-397. Available online at http://dx.doi.org/10.1162/qjec.2006.121.2.351.

Saxenian, AnnaLee (1999). "Silicon Valley's New Immigrant Entrepreneurs.” Public Policy Institute of California (1999). Available online at http://wee.ppic.org/content/pubs/report/R_699ASR.pdf

Shaw, Kathryn L. "Life-Cycle Labor Supply with Human Capital Accumulation" 
International Economic Review, Vol. 30; No. 2 (1989), pp. 431-456.

Somin, Ilya (2013). Democracy and Political Ignorance. Stanford University Press. ISBN 978-0804786614.

Storesletten, Kjetil. (2000) Sustaining Fiscal policy through Immigration, Journal of Political Economy 108, pp.300-323.

Wilkinson, Will (2009). "Thinking Clearly About Economic Inequality.” Cato Institute Policy Analysis No. 640 (July 14, 2009). Available online at http://www.cato.org/publications/policy-analysis/thinking-clearly-about-economicinequality.

Wolf, Douglas A., Lee, Ronald D., Miller, Timothy, Donehower, Gretchen, and Genest, Alexandre. "Fiscal Externalities of Becoming a Parent." Population Development Review, Vol. 37, No. 2 (June 2011), pp. 241-266. Available online at http://www.ncbi.nlm.nih.gov/pmc/articles/PMC3134288/. 
Notes

1 California actually adopted an anti-Okie law, but it was struck down in 1941, original newspaper available online: “Anti-Okie Law Ruled Void.” November 24, 1941. The Tuscaloosa News. http://news.google.com/newspapers?nid=1817\&dat=19411124\&id=qdQAAAAIBAJ\&sjid=uUwMAAAAIBAJ\&pg=3302,4023575. See also the memoir "The Difference Between an Illegal Immigrant and Me" by Robert Higgs, published February 20, 2008, available online at http://www.independent.org/newsroom/article.asp?id=2126

2 “Immigrant Numbers for October 2013." October, 2013. Visa Bulletin 61, p.2, available online at http://travel.state.gov/content/dam/visas/Bulletins/visabulletin_october2013.pdf.

3 See U.S. Department of State Bureau of Consular Affairs. "Employment-Based Immigrant Visa." http://travel.state.gov/content/visas/english/immigrate/types/employment.html, accessed May 1, 2014.

$4 \quad$ For the most recent figures, see United States Citizenship and Immigration Services. "USCIS Reaches FY 2015 H-1B Cap.” April 10, 2014. http://www.uscis.gov/news/uscis-reaches-fy-2015-h-1b-cap-0.

5 Martin, Daniel, and James Yankay. April 2013. "Refugees and Asylees: 2012.” Office of Immigration Statistics, http://www.dhs.gov/publication/refugees-and-asylees-2012. For a more detailed discussion of the various humanitarian statuses (temporary and long-term) offered by the United States government, see Landgrave, Michelangelo, May 14, 2014. "A Survey of the United States Humanitarian Migrant Statuses.” Open Borders: The Case. http://openborders.info/blog/a-survey-ofthe-united-states-humanitarian-migrant-statuses/

6 U.S. Department of State Bureau of Consular Affairs. "DV 2013 - Selected Entrants." http://travel.state.gov/content/visas/english/immigrate/diversity-visa/dv2013-slected-entrants.html, accessed May 1, 2014. The number of applicants for the Diversity Visa is misleadingly low because countries that have sent more than 50,000 immigrants to the U.S. in the previous five years are ineligible for the program. This rule excludes would-be immigrants from populous countries like India and China, as well as countries with strong historic ties such as the U.K. and Mexico.

7 See "Calculation of the Adjusted Visa Refusal Rate for Tourist and Business Travelers Under the Guidelines of the Visa Waiver Program," U.S. State Department, http://ravel.state.gov/content/dam/visas/Statistics/Non-Immigrant-Statistics/refusalratelanguage.pdf. For discussion on the challenges in the U.S. system, specifically the doctrine of consular nonreviewability, see Dobkin (2009).

8 Passel, Jeffrey, D’Vera Cohn, and Ana Gonzalez-Barrera. September 23, 2013. "Population Decline of Unauthorized Immigrants Stalls, May Have Reversed." PewResearch Hispanic Trends Project, p.6. Available online at http://www.pewhispanic.org/2013/09/23/population-decline-of-unauthorizedimmigrants-stalls-may-have-reversed/.

9 Economic Research Service/USDA. 2001. "Hired Farm Labor: Comparing the U.S. and Mexico." Agricultural Outlook, p.15 reports a Mexican daily wage of $\$ 3.60$, about $\$ 1000$ a year for a five day work-week.

10 Havocscope. "Prices Charged by Human Smugglers." http://www.havocscope.com/black-marketprices/human-smuggling-fees/, access May 1, 2014.

11 See BBC News. October 3, 2013. "Italy Boat Sinking: Hundreds Feared Dead off Lampedusa," http://www.bbc.co.uk/news/world-europe-24380247 for one of many stories of refugee boats sinking and ending in tragedy. See Frump, Bob. 2006. The Man-Eaters of Eden: Life and Death in Krueger National Park. Guilford, CT: Lyons Press, pp.132-6, for the risks that border-crossers to South Africa face from lions. 
12 Esipova, Neil, and Julie Ray. March 9, 2012. "More Adults Would Move for Temporary Work Than Permanently.” Gallup World. http://www.gallup.com/poll/153182/Adults-Move-Temporary-WorkPermanently.aspx

13 Phillip Connor, D'Vera Cohn and Ana Gonzalez-Barrera. December 17, 2013. "Changing Patterns of Global Migration and Remittances." Pew Research Center, http://www.pewsocialtrends.org/files/2013/12/global-migration-final_12-2013.pdf, p.4

14 Clifton, John. March 21, 2013. "More Than 100 Million Worldwide Dream of a Life in the U.S." Gallup World. http://www.gallup.com/poll/161435/100-million-worldwide-dream-life.aspx

15 Esipova, Neil, Rajesh Srinivasan, and Julie Rayand. November 6, 2009. "Potential Net Migration Could Change Countries." Gallup World, http://www.gallup.com/poll/124193/potential-net-migrationchange-developed-nations.aspx and Esipova, Neil, Rajesh Srinivasan, and Julie Rayand. January 17, 2014. "Potential Net Migration Index Declines in Many Countries. Gallup World, http://www.gallup.com/poll/166796/potential-net-migration-index-declines-countries.aspx

16 See Collier 2013, pp.27-56 for a detailed treatment of diaspora dynamics and its implications for migration flows.

17 See Whalen, Carmen. 2008. "Colonialism, Citizenship, and the Making of the Puerto Rican Diaspora: An Introduction.” In Whalen, Carmen, and Víctor Vázquez-Hernández, eds. 2008. The Puerto Rican Diaspora: Historical Perspectives. Philadelphia, PA: Temple University Press, p.2, available online at http://www.temple.edu/tempress/chapters_1400/1523_ch1.pdf. Note that the case of Puerto Rico is somewhat unusual in that Puerto Rico not only got open borders with the mainland United States but was also governed by US institutions.

18 See Grieco, Elizabeth, Yesenia Acosta, G. Patricia de la Cruz, Christine Gambino, Thomas Gryn, Luke Larsen, Edward Trevelyan, and Nathan Walters. May 2012. "The Foreign-Born Population in the United States: 2010.” United States Census Bureau, p.2, http://www.census.gov/prod/2012pubs/acs$\underline{19 . p d f}$

19 See Bohanon, Cecil, and T. Norman Van Cott. 2005. "Tariffs, Immigration, and Economic Insulation: A New View of the U.S. Post-Civil War Era." Independent Review 9, pp.529-542, available at http://www.independent.org/pdf/tir/tir 09 4 4 bohanon.pdf.

20 See Southeast Michigan Council of Governments. 2002. "Historical Population and Employment by Minor Civil Division, Southeast Michigan," http://library.semcog.org/InmagicGenie/DocumentFolder/HistoricalPopulationSEMI.pdf.

21 See Grieco et al., and "Table 1: Nativity of the Population and Place of Birth of the Native Population: 1850-1990.” May 9, 1999. United States Census Bureau, https://www.census.gov/population/www/documentation/twps0029/tab01.html.

22 Clemens, Montenegro, and Pritchett 2008 introduces the concept and estimates the value of the "place premium" to quantify the effect of location on worker productivity and earnings. For place premium estimates, see p.11.

23 Clemens 2011.

24 Woetzel, Jonathan, Lenny Mendonca, Janamitra Devan, Stefano Negri, Yangmei Hu, Luke Jordan, Xiujun Li, Alexander Maasry, Geoff Tsen, Flora Yu. March 2009. "Preparing for China's Urban Billion." McKinsey Global Institute, http://www.mckinsey.com/insights/urbanization/preparing_for_urban_billion_in_china. 
25 See Abbas, Rameez and Divya Varma. March 3, 2014. "Internal Labor Migration in India Raises Integration Challenges for Migrants." Migration Policy Institute, http://www.migrationpolicy.org/article/internal-labor-migration-india-raises-integration-challengesmigrants.

26 Sankhe, Shirish, Ireena Vittal, Richard Dobbs, Ajit Mohan, Ankur Gulati, Jonathan Ablett, Shishir Gupta, Alex Kim, Sudipto Paul, Aditya Sanghvi, Gurpreet Sethy. "India's Urban Awakening: Building Inclusive Cities, Sustaining Economic Growth," McKinsey Global Institute, http://www.mckinsey.com/insights/urbanization/urban_awakening_in_india.

27 We owe this adage to Michael Clemens.

28 See Yang, Dean. 2011. “Migrant Remittances.” Journal of Economic Perspectives, pp.129-52.

29 Guest 2011 includes many examples of such businesses.

30 The World Bank http://data.worldbank.org/indicator/NY.GDP.PCAP.CD/countries/PR?display=graph estimates the nominal GDP per capita in Puerto Rico at $\$ 27,000$, comparable to Spain.

31 See Barro and Sala-i-Martin 2003.

32 “Law of Return 5710-1950." Israel Ministry of Foreign Affairs. http://www.mfa.gov.il/MFA/MFAArchive/1950-1959/Pages/Law\%20of\%20Return\%205710-1950.aspx

33 See Legrain 2007, pp. 133-135.

$34 \quad$ From Kerr and Kerr 2011, p.14.

35 In the United States, housing prices and rents rise by roughly 1 percent when immigration raises a city's population by 1 percent (Saiz 2007, 2003). Gonzalez and Ortega (2009) find an even larger effect for Spain. The U.S. home ownership rate is about $66 \%$, so the benefits of appreciation would be widely dispersed.

36 See Borjas and Katz 2005.

37 Ottaviano and Peri 2012.

38 See Docquier and Rapoport 2012.

39 See for instance Saxenian 1999 and Rampell, Catherine. July 1, 2013. "Immigration and Entrepreneurship.” New York Times Economix Blog, http://economix.blogs.nytimes.com/2013/07/01/immigration-and-entrepreneurship/.

$40 \quad$ See Khan and Sokoloff 1993.

$41 \quad$ Sala-i-Martin 2006.

42 Sala-i-Martin 2006, pp.372-5.

43 Chandy and Gertz 2011, pp.3-4.

44 See Shulman, Carl, May 27, 2014. "How migration liberalization might eliminate most absolute poverty." http://reflectivedisequilibrium.blogspot.com/2014/05/how-migration-liberalizationmight.html 
45 Sala-i-Martin 2006, pp. 383-6.

46 For further discussion, see Milanovic 2012a, 2012b..

47 Wilkinson 2009 critiques a passage making the argument that immigration increases poverty and inequality by writing: "This is a sadly typical example of the distortions of analytical nationalism. If we were to assume a natural and mundane moral perspective, from which all people involved are taken into account and assumed to have equal worth - that is, if we assume the perspective of moral egalitarianism - what we would see is a profound reduction in both poverty and economic inequality. If the question is 'What happened to the people in this scenario?' then the answer is 'The poorest people became considerably wealthier, narrowing the economic gap between them and the rest.' But what actually happened seems either invisible or irrelevant to the authors, which certainly suggests that their analytical framework leaves something to be desired. Here's how the passage I highlighted might be more accurately stated: Immigration decreased inequality both directly, by sharply increasing the wages of low-skilled, foreign-born workers, and indirectly, through remittance payments to lowincome relatives at the immigrants' places of origin. Due to the widespread opposition of American voters to liberalizing immigration, very large additional reductions in poverty and inequality have been foregone."

See Kerr and Kerr 2011, pp.15-21.

$49 \quad$ See $\mathrm{Ku}$ and Bruen 2013.

$50 \quad$ Butcher and Piehl 2007. See also Rumbaut, Rubén, Roberto Gonzales, Golnaz Komaie, and Charlie Morgan. June 1, 2006. "Debunking the Myth of Immigrant Criminality: Imprisonment Among Firstand Second-Generation Young Men," http://www.migrationinformation.org/usfocus/display.cfm?ID=403, which shows lower foreign-born incarceration rates in total, within each ethnicity, and for every combination of ethnicity and high school graduation status.

51 Maciamo. June 15, 2004. "Foreign Criminality in Japan,” Wa-pedia, http://www.wapedia.com/gaijin/foreign_crime in_japan.shtml.

52 See United Nations Office on Drugs and Crime. 2011. "Global Study on Homicide," p.45. http://www.unodc.org/documents/data-andanalysis/statistics/Homicide/Globa_study on homicide_2011_web.pdf.

53 In economic jargon, voting has "political externalities." For an extended discussion, see "Political Externalities." Open Borders: The Case, http://openborders.info/political-externalities.

$54 \quad$ See Caplan 2007 and Somin 2013.

55 Pashler 2013.

56 GSS variable identifiers POLVIEWS and BORN.

57 GSS variable identifier TAXSPEND.

58 GSS variable identifiers JOBSALL, PRICECON, HLTHCARE, AIDOL. AIDINDUS, AIDUNEMP, EQUALIZE, AIDCOL, and AIDHOUSE. We summed responses to all eight variables to get an index of economic liberalism.

$59 \quad$ GSS variable identifier LETIN1.

60 GSS variable identifiers SPKATH, SPKRAC, SPKCOM, SPKMIL, and SPKHOMO. We summed 
responses to all five variables to get an index of social liberalism. The GSS also features a sixth free speech question, SPKSOC, but the years in which it was asked (1972-4) do not overlap with the other free speech questions.

$61 \quad$ U.S. Citizenship and Immigration Services. "Citizenship Through Naturalization." http://www.uscis.gov/us-citizenship/citizenship-through-naturalization, accessed May 1, 2014. Spouses of U.S. citizens must wait three years to apply.

62 Caplan (2012) writes: "[I]mmigrants and their descendents have lower voter turnout than natives (Xu 2005; Cassel 2002). Looking at 2000 data, Citrin and Highton (2002: 16) found that Hispanics were 26 percent of California's adult population, 18 percent of its citizen population, and only 14 percent of its voting population. For the United States as a whole, Hispanics were 5 percent of the adult population, 3 percent of its citizen population, and just 2 percent of its voting population. Roughly the same pattern holds for Asians. Citrin and Highton (2002: 67-74) project that in 2040, whites will be just over a third of California's population but remain 53 percent of its voters. Nonlibertarians often treat immigrants' low turnout as yet another strike against them. But if you fear political externalities, immigrants' political apathy is a blessing in disguise."

63 GSS variable identifier VOTE08.

64 See especially Gilens 2012.

65 See the literature review in Gochenour and Nowrasteh 2014.

66 See especially Alesina, Glaeser, and Sacerdote 2001, and Gilens 1999.

67 See the literature review in Gochenour and Nowrasteh 2014.

68 See Gochenour and Nowrasteh 2014.

69 See also Carens 2013 and "Economic and Moral Factors in Favor of Open Immigration" by Alex Tabarrok, The Independent Institute, 2000, http://www.independent.org/issues/article.asp?id=486.

70 Landsburg 2012, pp.73-87.

71 See Milanovic 2012a.

72 See Smith, Nathan. January 28, 2013. "Rawls' Highly Unpersuasive Attempt to Evade the Open Borders Ramifications of his Own Theory." Open Borders: The Case, http://openborders.info/blog/rawls-highly-unpersuasive-attempt-to-evade-the-open-bordersramifications-of-his-own-theory/ on why Rawlsianism requires open borders

73 See Bader, Veit, 2005. “The Ethics of Immigration.” Constellations, Vol. 12, No. 3. http://dare.uva.nl/document/50299?origin=publication_detail

74 Sen, Amartya. 2005. "Human Rights and Capabilities." Journal of Human Development 6, pp.151-66; Nussbaum, Martha. 2001. Women and Human Development: The Capabilities Approach. Cambridge: Cambridge University Press.

75 See Risse 2009.

76 On Rand, see e.g. Mayhew, Robert, ed. 2005. Ayn Rand Answers: The Best of Her $Q$ \& A. NY: Penguin Books, p.25. In Radicals for Capitalism, Brian Doherty documents Rothbard's early support for free migration. During the 1950s, Rothbard broke ranks with the then nascent right in the US led by Buckley, partly over their lack of support for free immigration (p. 258). In the 1970s, he attacked the 
recently formed Libertarian Party for conditioning support for free immigration on the prior dismantling of the welfare state (p. 417). Rothbard changed his mind on for free migration shortly before his death. See "Nations By Consent: Decomposing the Nation-State" for the Journal of Libertarian Studies (11:1, Fall 1994), available online at http://www.mises.org/journals/jls/11_1/11_1_1.pdf.

77 Huemer (2010) expands on this style of argument: he starts with the libertarian presumption against coercion, notes that migration restrictions are imposed coercively, then finds that the arguments offered for migration restrictions fail to overcome the presumption. Caplan (2012) follows a similar approach, but is more focused on the empirical evidence than on the moral considerations.

78 Brennan 2011 plausibly argues that poorly informed voters are morally obliged not to vote.

79 For an extended discussion, see "Christian View of Immigration." Open Borders: The Case, http://openborders.info/christian-views-of-immigration/.

80 Sailer, Steve. February 13, 2006. “Americans First.” The American Conservative, http://www.theamericanconservative.com/article/2006/feb/13/00012/ is his most definitive article on citizenism. For further discussion, see "Citizenism." Open Borders: The Case, http://openborders.info/citizenism.

81 For details on the World Values Survey migration results, see Smith, Nathan. December 3, 2012. "Who Favors Open Borders?" Open Borders: The Case, http://openborders.info/blog/who-favors-openborders.

82 Harford, Tim 2007, p.123.

83 For further discussion, see Caplan 2012, and "Keyhole solutions." Open Borders: The Case, http://openborders.info/keyhole-solutions.

84 See Greenhouse, Linda. April 8, 2010. “Across the Border, Over the Line" New York Times Opinionator blog, http://opinionator.blogs.nytimes.com/2010/04/08/across-the-border-over-the-line/.

85 See "Ending Apartheid," The Economist, April 19, 2014, http://www.economist.com/news/specialreport/21600798-chinas-reforms-work-its-citizens-have-be-made-more-equal-ending-apartheid.

86 See Han, Kirsten. November 8, 2013. "Singapore's Exploited Immigrant Workers" The Daily Beast, http://www.thedailybeast.com/articles/2013/11/08/singapore-s-exploited-immigrant-workers.html, and Malit, Froilan, and Ali Youha. September 18, 2013. "Labor Migration in the United Arab Emirates: Challenges and Responses." Migration Policy Institute, http://www.migrationpolicy.org/article/labormigration-united-arab-emirates-challenges-and-responses.

87 The wait time for stateless migrants is four years. See http://www.migrationsverket.se/English/Privateindividuals/Becoming-a-Swedish-citizen/Citizenship-for-adults/Time-in-Sweden.html.

88 O’Riordan and Cameron 1994.

89 See Caplan (2007), as well as Rubin's (2003) effort to ground Caplan in evolutionary psychology.

90 See especially Kahneman, Daniel. 2011. Thinking, Fast and Slow. NY: Farrar, Straus and Giroux

91 See Howley, Kerry. February 2008. "Ending Global Apartheid.” Reason, http://reason.com/archives/2008/01/24/ending-global-apartheid. The examples of Jim Crow and apartheid are taken because readers are likely to be most familiar with them, but similar examples can be found around the world, many of them historically propped up by governments or local leaders. The 
institution of human slavery around the world, the caste system in India, and the class divisions in medieval Europe were considered normal for a long time and yet came to be considered obviously immoral by people later. 
